\title{
LET'TER
}

\section{IN DEFENCE OF THE WRITER'S THEORY OF THE EVOLUTION OF THE AUDITORY CONDUCTING APPARATUS}

Recently, Dr. Parrington (Ref. J. Laryng. and Otol., Oct., 1949, Vol. LXIII, No. Io, pp. 580-595) has criticized certain aspects of the theory which I outlined in this JouRnal in April, I949. I must reject his argument for the following reasons :

(I) He has confined himself almost entirely to matters of pure palæontology and has ignored much of the morphological and embryological evidence.

(2) His conception of the mechanics of a vibrating system is not in accord with established physical principles.

These are the two main criticisms which $I$ originally levelled against the orthodox theory and Dr. Parrington has not attempted to answer them. Furthermore, his quotations from my own work are not free from error. Unfortunately, space is not at present available in the JouRnaL for a full discussion of the above points but I hope, at some later date, to publish the results of some further research which we are conducting into the embryology, morphology and mechanics of the middle ear. At the same time, I shall show that the palæontological " facts " to which Dr. Parrington refers are in no way incompatible with my theory provided that the theory is explicitly stated and clearly understood.

A. TUMarkin.

\section{GENERAL NOTES}

THE following lectures have been arranged jointly between the Royal College of Surgeons of England and the Institute of Laryngology and Otology, to take place at 5 p.m. on the following dates at the Royal College of Surgeons, Lincoln's Inn Fields, London, W.C.2 :-

Thursday, January 5th, I950. Mr. Rainsford Mowlem: "Injuries of the nose and sinuses".

Thursday, February 2nd, I950. Professor W. Barnard: "The contribution of pathology to the diagnosis of tumours in otolaryngology".

Thursday, March 2nd, I950. Professor B. Windeyer with Mr. C. P. Wilson : "The treatment of malignant disease of the paranasal sinuses".

Thursday, May 4th, r950. Mr. V. E. Negus: "The evolution and treatment of pharyngeal diverticula".

Thursday, July 6th, I950. Sir Gordon Gordon-Taylor : "Glands in the neck ". 